\title{
Courcelles-Chaussy - Landonvillers
}

Lotissement Le Clos des Jardins

\section{Gilles Mangin}

\section{(2) OpenEdition \\ Journals}

Édition électronique

URL : http://journals.openedition.org/adlfi/9075

ISSN : 2114-0502

Éditeur

Ministère de la culture

Référence électronique

Gilles Mangin, "Courcelles-Chaussy - Landonvillers », ADLFI. Archéologie de la France - Informations [En ligne], Lorraine, mis en ligne le 01 mars 2001, consulté le 19 avril 2019. URL : http:// journals.openedition.org/adlfi/9075

Ce document a été généré automatiquement le 19 avril 2019

(C) Ministère de la Culture et de la Communication, CNRS 


\title{
Courcelles-Chaussy - Landonvillers
}

Lotissement Le Clos des Jardins

\author{
Gilles Mangin
}

Identifiant de l'opération archéologique : F1357200100024

Date de l'opération : 2001 (EV)

L'opération de sondages archéologiques menée sur une superficie de $6601 \mathrm{~m}^{2}$, dans le cadre de la création du lotissement privé «Le Clos des Jardins » à Landonvillers, localité rattachée à Courcelles-Chaussy, n'a pas permis de repérer le moindre indice de vestiges archéologiques.

INDEX

Index géographique : Lorraine, Moselle (57), Landonvillers operation Fouille d'évaluation (EV)

\section{AUTEURS}

GILLES MANGIN

AFAN 